\title{
Plasma Surface Modification of Chitosan Membranes: Characterization and Preliminary Cell Response Studies
}

\author{
Simone S. Silva, * Sandra M. Luna, Manuela E. Gomes, Johan Benesch, \\ Iva Pashkuleva, João F. Mano, Rui L. Reis
}

Surface modification of biomaterials is a way to tailor cell responses whilst retaining the bulk properties. In this work, chitosan membranes were prepared by solvent casting and treated with nitrogen or argon plasma at $20 \mathrm{~W}$ for 10-40 min. AFM indicated an increase in the surface roughness as a result of the ongoing etching process. XPS and contact angle measurements showed different surface elemental compositions and higher surface free energy. The MTS test and direct contact assays with an L929 fibroblast cell line indicated that the plasma treatment improved the cell adhesion and proliferation. Overall, the results demonstrated that such plasma treatments could significantly improve the biocompatibility of chitosan membranes and thus improve their potential in wound dressings and tissue engineering applications.

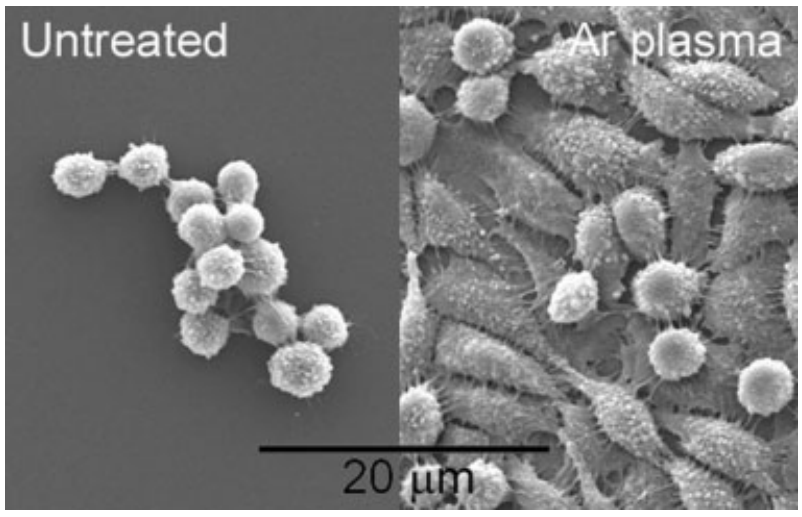

\section{Introduction}

Every year millions of people suffer cutaneous lesions such as burns, abrasions or wounds that need treatment. When

S. S. Silva, S. M. Luna, M. E. Gomes, J. Benesch, I. Pashkuleva, J. F. Mano, R. L. Reis

3B's Research Group - Biomaterials, Biodegradables and Biomimetics, Department of Polymer Engineering, Campus de Gualtar, 4710-057 Braga, Portugal

Fax: +351253604 498; E-mail: simonesilva@dep.uminho.pt S. S. Silva, S. M. Luna, M. E. Gomes, J. Benesch, I. Pashkuleva, J. F. Mano, R. L. Reis

IBB - Institute for Biotechnology and Bioengineering, PT

Government Associated Laboratory, Braga, Portugal the skin is wounded, cellular damage, loss of tissue and changes in the relationship between the tissues and the surrounding environment are correlated in a complex series of cellular and chemical events. ${ }^{[1]}$ It is well established that severely damaged skin requires a protective barrier for proper healing. Effective wound dressing must not only protect the wound from the surrounding environment but also promote the healing process by providing an optimal microenvironment. ${ }^{[2,3]}$ Polysaccharides have been widely used in wound management aids. Due to their relative versatility in terms of composition, structure and intrinsic properties, they can assist with the proper physiological reconstruction of the skin and reduce or prevent scar tissue formation. ${ }^{[4]}$ 
Some of the thoroughly studied natural polymers for skin regeneration are alginate, chitosan, hyaluronic acid, cellulose, collagen, gelatin and their derivatives. ${ }^{[3-10]}$ These polymers can be used as gelling agents, consistency excipients in creams, matrices in patches, sponge-type wound dressings, hydrogels, membranes and skin adhesives in transdermal systems. ${ }^{[3-11]}$ Among them, chitosan possesses several characteristics favorable for promoting dermal regeneration and accelerated wound healing. ${ }^{[5,12]}$ Its biodegradability, adhesiveness, non-toxicity, bacteriostatic, fungistatic and haemostatic activities, and antimicrobial effects make this polysaccharide an excellent biomaterial to treat wounds..$^{[5,12-15]}$ Several studies ${ }^{[16,17]}$ have shown that chitosan-derived membranes are not cytotoxic towards fibroblasts, but tend to inhibit cell proliferation. Thus, significant research efforts have been focused on improving the host response to these materials in terms of cellular behavior. Earlier studies used a variety of methods such as blending, ${ }^{[16]}$ gamma irradiation, ${ }^{[18]}$ chemical reactions ${ }^{[19]}$ and plasma surface modification. ${ }^{[20-23]}$ The last one of these, plasma surface modification, is a method widely used ${ }^{[23-25]}$ to tailor surface functionality by working in different atmospheres. The commonly used oxygen plasma results in the formation of different oxygen containing groups, such as $-\mathrm{OH},-\mathrm{C}=\mathrm{O}$, $-\mathrm{COOH}$. Argon and nitrogen are other examples of gases used in plasma treatment. ${ }^{[26-29]}$ As a result of the introduced changes in the surface chemistry, different cell behavior on the modified material can be

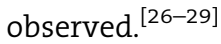

The aim of this study was to improve the biocompatibility of chitosan membranes in terms of fibroblast responses in vitro. Two sets of experiments using nitrogen and argon treatments for different times were carried out. In vitro biological assays with L929 fibroblast-like cells were performed to evaluate the influence of the introduced changes on cell behavior on a preliminary basis. To the best of our knowledge, there is no other study that has compared the effect of these surface treatments of chitosan membranes on fibroblast responses.

\section{Experimental Part}

\section{Materials and Sample Preparation}

Chitosan (Cht, Sigma Aldrich, CAS 9012-76-4) with a deacetylation degree of $83.8 \%$, as determined by ${ }^{1} \mathrm{H} N M R,{ }^{[30]}$ was used. All other reagents were of analytical grade and used as received. Chitosan powder was dissolved at 1 wt.-\% in $0.2 \mathrm{~m}$ acetic acid. Chitosan membranes (average thickness of $47 \mu \mathrm{m}$ ) were obtained by a solvent casting technique, followed by neutralization in a $0.1 \mathrm{M}$ $\mathrm{NaOH}$ solution for $30 \mathrm{~min}$. The plasma treatment was carried out in a radio frequency plasma reactor (PlasmaPrep5, Germany). The plasma chamber was thoroughly purged with a continuous flow of the gas used during the treatment to reduce trace amounts of air
Table 1. Plasma conditions used for modification of chitosan membranes.

\begin{tabular}{|c|c|c|c|}
\hline \multirow[t]{3}{*}{ Sample } & \multicolumn{3}{|c|}{ Conditions } \\
\hline & Power & Time & Gas \\
\hline & $\mathbf{W}$ & $\min$ & \\
\hline ChtP1 & 20 & 10 & $\mathrm{~N}_{2}$ \\
\hline ChtP2 & 20 & 20 & $\mathrm{~N}_{2}$ \\
\hline ChtP3 & 20 & 30 & $\mathrm{~N}_{2}$ \\
\hline ChtP4 & 20 & 40 & $\mathrm{~N}_{2}$ \\
\hline ChtP5 & 20 & 10 & $\mathrm{Ar}$ \\
\hline ChtP6 & 20 & 20 & $\mathrm{Ar}$ \\
\hline ChtP7 & 20 & 30 & $\mathrm{Ar}$ \\
\hline ChtP8 & 20 & 40 & $\mathrm{Ar}$ \\
\hline
\end{tabular}

and moisture. During the treatment, the gas flow was adjusted in order to keep a constant pressure of 0.2 mbar insight the chamber. A power of $20 \mathrm{~W}$ was applied. The duration of the treatment was varied from $10 \mathrm{~min}$ to $40 \mathrm{~min}$. Two different working gases, namely nitrogen $\left(\mathrm{N}_{2}\right)$ and argon (Ar) (see Table 1 that also contains designation codes for each treatment), were used in order to evaluate the effect of the working gas on the induced changes in the surface functionalities.

\section{Characterization Methods}

\section{Scanning Electron Microscopy (SEM)}

The surface morphology of the samples was analyzed using a Leica Cambridge S-360 scanning electron microscope. All specimens were pre-coated with a conductive layer of sputtered gold. The micrographs were taken at $10 \mathrm{kV}$ at different magnifications.

\section{Atomic Force Microscopy (AFM)}

The roughness of the sample surface was measured by AFM. The analyses were performed on at least three spots per sample using tapping mode (Veeco, USA) connected to a NanoScope III (Veeco, USA) with non-contacting silicon nanoprobes (ca. $300 \mathrm{kHz}$, setpoint 2-3 V) from Nanosensors, Switzerland. All images were fitted to a plane using the 3rd degrees flatten procedure included in NanoScope software version $4.43 \mathrm{r} 8$. The surface roughness was calculated as $S q$ (root mean square from average flat surface) and Sa (average absolute distance from average flat surface). The values are presented as mean \pm standard deviation.

\section{X-Ray Photoelectron Spectroscopy (XPS)}

The XPS analysis was performed using an ESCALAB 200A (VG Scientific, UK) with PISCES software for data acquisition and analysis. For analysis, an achromatic Al $(\mathrm{K} \alpha)$ X-ray source operating at $15 \mathrm{kV}(300 \mathrm{~W})$ was used. The spectrometer was calibrated with reference to $\mathrm{Ag} 3 \mathrm{~d} 5 / 2(368.27 \mathrm{eV})$ and was 
operated in constant analyzer energy (CAE) mode with $20 \mathrm{eV}$ pass energy. The measurements were carried out at a take-off angle of $90^{\circ}$ (normal to the surface). Data acquisition was performed at a pressure lower than $10^{-6} \mathrm{~Pa}$. The value of $285 \mathrm{eV}$ of the hydrocarbon C1s core level was used as a calibration for the absolute energy scale. Overlapping peaks were resolved into their individual components by XPSPEAK 4.1 software.

\section{Contact Angle Measurements}

The surface wettability of the membranes was assessed by static contact angle $(\theta)$ measurements using the sessile drop method. Two different liquids were used: ultra-pure water (polar) and diiodomethane (non-polar). The measurements were performed using OCA20 equipment (DataPhysics, Germany) and SCA-20 software. The presented data are the average of 6 measurements. The surface energy was calculated using the Owens, Wendt, Rabel and Kaelble (OWRK) equation. ${ }^{[31]}$

\section{in vitro Cell Culture Studies}

\section{Cell Culture}

A mouse fibroblast-like cell line (L929) was selected for all the biological assays in order to evaluate the effect of surface modification on cell adhesion, viability and proliferation. The L929 fibroblast cell line was obtained from the European Collection of Cell Cultures (ECACC, UK). The cells were cultured in Dulbecco's Modified Eagle's Medium (DMEM, Sigma-Aldrich, USA), supplemented with $10 \%$ of heat inactivated fetal bovine serum (FBS, Biochrom AG, Germany) and 1\% antibiotic/antimycotic solution (Invitrogen, Portugal) incubated at $37^{\circ} \mathrm{C}$ in a humidified atmosphere with $5 \%$ of $\mathrm{CO}_{2}$. The culture medium was changed every $2 \mathrm{~d}$.

\section{Direct Contact Assay - Cell Adhesion and Proliferation on} Chitosan Membranes

Chitosan membranes ( $1 \mathrm{~cm}^{2}$ modified and non-modified) were seeded with $100 \mu \mathrm{L}$ of a cell suspension $\left(8 \times 10^{4}\right.$ cells $\left.\cdot \mathrm{mL}^{-1}\right)$ and cultured for 3,7 and $14 \mathrm{~d}$ at $37^{\circ} \mathrm{C}$. Tissue culture polystyrene coverslips (TCPS, Sarstedt, USA) were used as controls. After each incubation period, the samples were rinsed with a phosphate buffer saline (PBS, Sigma-Aldrich, USA) and prepared for further analysis (MTS assay and SEM observations).

Prior to culturing, all the membranes were sterilized with ethylene oxide under previously described conditions. ${ }^{[32]}$

\section{MTS Assay}

Cellular viability was quantitatively assessed by the MTS [3-(4,5dimethylthiazol-2-yl)-5-(3-carboxymethoxyphenyl)-2-(4-sulfophenyl)2H-tetrazolium] assay (Promega, Madison, USA). ${ }^{[33]}$ Culture medium without FBS and without phenol red was mixed with MTS in the ratio 5:1, added to the membrane/cells constructs until it totally covered them and incubated for $3 \mathrm{~h}$ at $37^{\circ} \mathrm{C}$ in a $5 \% \mathrm{CO}_{2}$ atmosphere. After the incubation period, the optical density (OD) was read in a microplate reader (Bio-Tek, USA) at $490 \mathrm{~nm}$. The measurements were made in triplicate for each treatment and time point (3, 7 and $14 \mathrm{~d})$.

\section{SEM Analysis of the Membranes}

Prior to SEM measurements, the seeded membranes were fixed with $2.5 \%$ glutaraldehyde (Sigma-Aldrich, Germany) in a PBS solution and then dehydrated using a series of ethanol solutions $(25,30,50,70,80,90,100 \% \mathrm{v} / \mathrm{v})$. The samples were dried overnight at room temperature, coated with gold by sputtering and observed by SEM.

\section{Results and Discussion}

When a polymer is exposed to plasma, two competitive processes, namely functionalization and etching, take place. In a typical plasma process, the radicals created on the polymer surface by hydrogen removal combine with the radicals from the working gas to modify the surface. Alternatively, crosslinking could occur when the created radicals on the surface recombine with themselves. On the other hand, etching will also take place. The working conditions determine which processes will be dominant. ${ }^{[24,25]}$ SEM images of the modified membranes did not show any significant changes in the surface morphology induced by the treatments (data not shown). Nevertheless, ongoing etching processes were confirmed by AFM. Changes in the surface topography after the performed modification were observed at the nanoscale (Figure 1). This effect was more significant after longer exposure times (30 and $40 \mathrm{~min}$ ), when nitrogen was used as a working gas. In contrast to this, a shorter exposure time (10 and $20 \mathrm{~min}$ ) was more effective when the modification was performed in an argon plasma atmosphere. The roughness of the argon plasma treated membranes (Figure 2B) decreased with longer exposure times (40 min) but the modified membranes were thinner compared to the untreated membranes. Additionally, the treated membranes were more brittle, which indicates crosslinking processes.

The surface chemistry of modified and non-modified samples was investigated by XPS. Since the argon atmosphere is a non-reactive gas, mainly etching was expected to be observed after this treatment. As can be seen from Table 2 a significant increase in the nitrogen content was observed for shorter treatment times (10 and $20 \mathrm{~min}$ ). Cleavage of the remaining $-\mathrm{COCH}_{3}$ groups of chitosan is most probably the reason for the obtained results. This hypothesis was confirmed by an observed decrease in the intensity of the carbon peak in the ChtP5 spectrum. However, when the treatment was extended, this relation was not that straightforward. For longer treatment times, the reactive species created by the plasma etch the already modified surface and therefore reveal a non-modified 

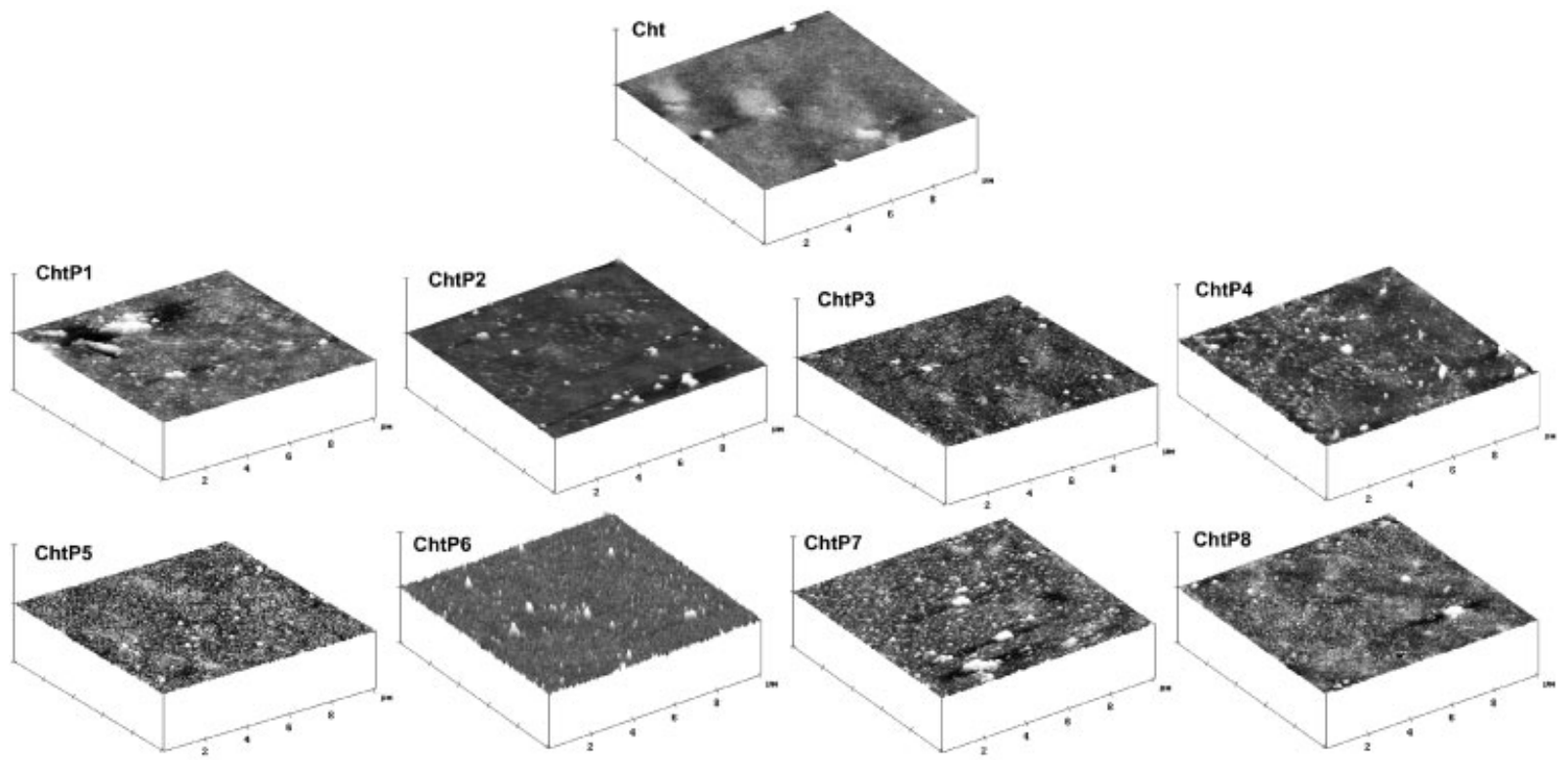

Figure 1. AFM images of chitosan membranes before (Cht) and after plasma treatment (ChtP1, ChtP2, ChtP3, ChtP4: nitrogen plasma; ChtP5, ChtP6, ChtP7, ChtP8: argon plasma).

surface. Hence, the values for $\mathrm{C}$ and $\mathrm{N}$ content obtained from the XPS spectra of the samples treated for $40 \mathrm{~min}$ (the longest time) are very similar to the initial ones for untreated chitosan (Table 2). When nitrogen is used as a working gas, not only etching but also functionalization
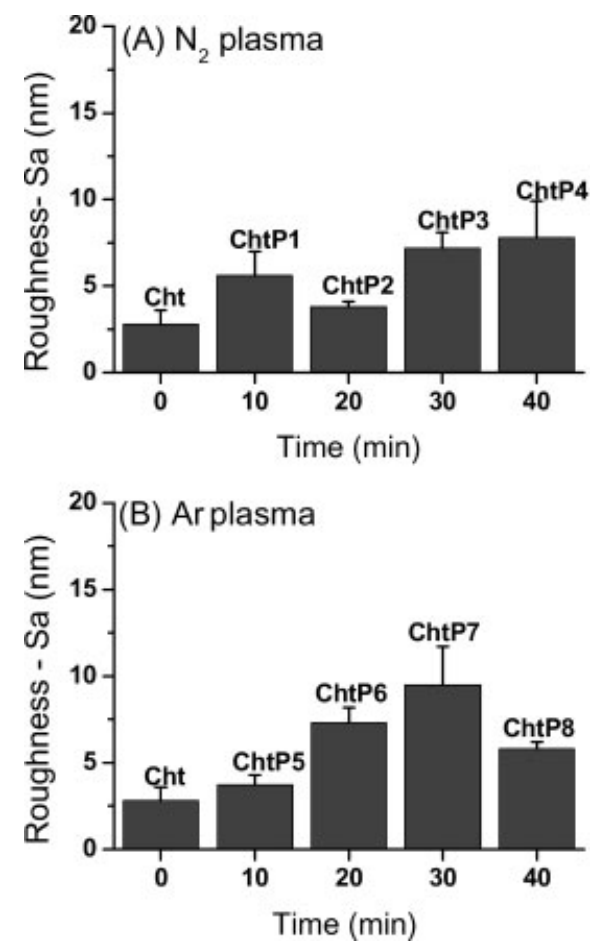

Figure 2. Mean roughness of chitosan membranes before and after nitrogen (A) and argon (B) plasma treatment. with $\mathrm{N}$-containing groups $\left(-\mathrm{NH}_{2},-\mathrm{NH},=\mathrm{NH}, \mathrm{CONH}_{2}\right.$ or $\mathrm{C} \equiv \mathrm{N}$ ) must be observed. ${ }^{[28]}$ Longer exposure times (30 and $40 \mathrm{~min}$ ) resulted in higher nitrogen contents (Table 2), confirming the incorporation of these groups on the material surface.

Changes in the high resolution $\mathrm{C}_{1 \mathrm{~s}}$ core level spectra before and after nitrogen and argon plasma treatment are shown in Figure 3 . The $C_{1 \text { s }}$ core level spectrum of the chitosan membranes revealed three peaks. The $C_{1 s}$ peak at $285.0 \mathrm{eV}$ was assigned to the main backbone carbon peak,

Table 2. Surface composition and atomic ratios determined by XPS for original and modified membranes.

\begin{tabular}{|c|c|c|c|c|c|c|}
\hline \multirow[t]{3}{*}{ Treatment } & \multirow[t]{3}{*}{ Sample } & \multicolumn{3}{|c|}{$\begin{array}{l}\text { Surface compo- } \\
\text { sition }\end{array}$} & \multirow{2}{*}{\multicolumn{2}{|c|}{$\begin{array}{c}\begin{array}{c}\text { Atomic } \\
\text { ratio }\end{array} \\
\%\end{array}$}} \\
\hline & & \multirow[t]{2}{*}{$\% \mathrm{C}$} & \multirow[t]{2}{*}{$\% 0$} & \multirow[t]{2}{*}{$\% \mathbf{N}$} & & \\
\hline & & & & & $\begin{array}{c}\mathrm{C} / \mathrm{O} \\
\text { ratio }\end{array}$ & $\begin{array}{l}\mathrm{C} / \mathrm{N} \\
\text { ratio }\end{array}$ \\
\hline none & chitosan & 66.41 & 27.97 & 5.62 & 2.37 & 11.82 \\
\hline $\mathrm{N}_{2}$ plasma & ChtP1 & 64.06 & 30.24 & 5.70 & 2.12 & 11.24 \\
\hline $\mathrm{N}_{2}$ plasma & ChtP2 & 70.33 & 24.24 & 5.33 & 2.90 & 13.20 \\
\hline $\mathrm{N}_{2}$ plasma & ChtP3 & 70.04 & 21.43 & 8.53 & 3.27 & 8.21 \\
\hline $\mathrm{N}_{2}$ plasma & ChtP4 & 67.88 & 24.61 & 7.50 & 2.76 & 9.05 \\
\hline Ar plasma & ChtP5 & 63.31 & 28.61 & 8.08 & 2.21 & 7.84 \\
\hline Ar plasma & ChtP6 & 66.80 & 24.43 & 8.78 & 2.73 & 7.61 \\
\hline Ar plasma & ChtP7 & 69.15 & 24.31 & 6.54 & 2.84 & 10.57 \\
\hline Ar plasma & ChtP8 & 65.61 & 28.61 & 5.79 & 2.29 & 11.33 \\
\hline
\end{tabular}


Macromolecular

Bioscience

S. S. Silva et al.
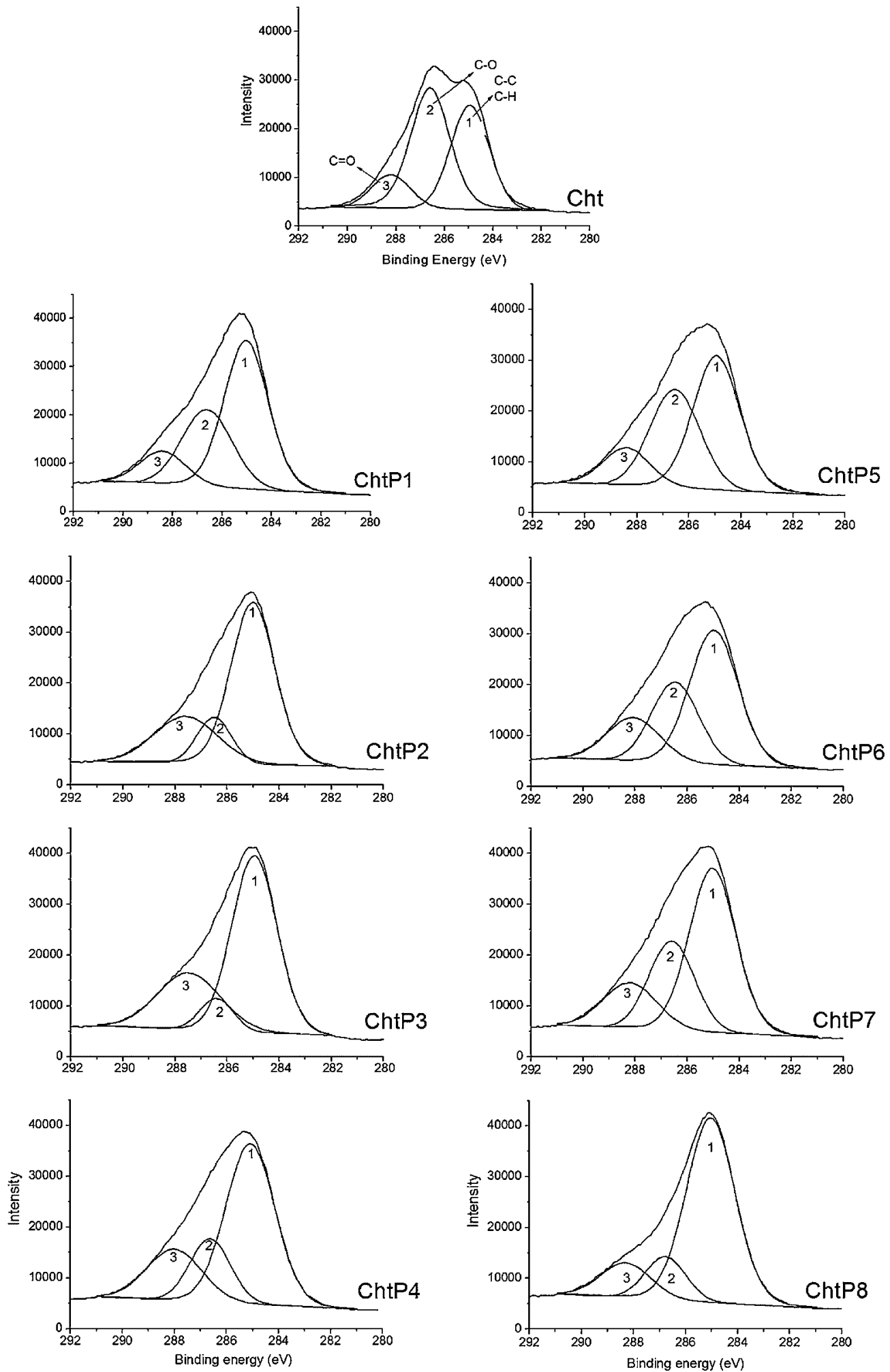

Figure 3. $\mathrm{C}_{15}$ core level spectra of untreated chitosan (Cht) and modified samples (ChtP1, ChtP2, ChtP3, ChtP4 - samples after nitrogen plasma; ChtP5, ChtP6, ChtP7, ChtP8 - samples after argon plasma).

572

Macromol. Biosci. 2008, 8, 568-576

(c) 2008 WILEY-VCH Verlag GmbH \& Co. KGaA, Weinheim

DOI: $10.1002 / \mathrm{mabi} .200700264$ 
Table 3. Relative intensities of the fitted C1s peak of untreated and modified plasma membranes.

\begin{tabular}{|c|c|c|c|}
\hline \multirow[t]{2}{*}{ Treatment } & \multirow[t]{2}{*}{ Sample } & Binding energy (relative intensity \%) & \multirow[t]{2}{*}{ Assignments } \\
\hline & & eV & \\
\hline \multirow[t]{3}{*}{ none } & Cht & $285.0(39)$ & $\mathrm{C}-\mathrm{C}, \mathrm{C}-\mathrm{H}$ \\
\hline & & $286.6(44)$ & $\mathrm{C}-\mathrm{O}$ \\
\hline & & $288.2(16)$ & $\mathrm{C}-\mathrm{O}-\mathrm{C}, \mathrm{N}-\mathrm{C}=\mathrm{O}$ \\
\hline \multirow[t]{3}{*}{$\mathrm{N}_{2}$ plasma } & ChtP1 & $285.0(56)$ & $\mathrm{C}-\mathrm{C}, \mathrm{C}-\mathrm{H}$ \\
\hline & & $286.6(31)$ & $\mathrm{C}-\mathrm{O}$ \\
\hline & & $288.4(12)$ & $\mathrm{C}-\mathrm{O}-\mathrm{C}, \mathrm{N}-\mathrm{C}=\mathrm{O}$ \\
\hline \multirow[t]{3}{*}{$\mathrm{N}_{2}$ plasma } & ChtP2 & $285.0(63)$ & $\mathrm{C}-\mathrm{C}, \mathrm{C}-\mathrm{H}$ \\
\hline & & $286.5(13)$ & $\mathrm{C}-\mathrm{O}$ \\
\hline & & $287.6(25)$ & $\mathrm{C}-\mathrm{O}-\mathrm{C}, \mathrm{N}-\mathrm{C}=\mathrm{O}$ \\
\hline \multirow[t]{3}{*}{$\mathrm{N}_{2}$ plasma } & ChtP3 & $284.9(64)$ & $\mathrm{C}-\mathrm{C}, \mathrm{C}-\mathrm{H}$ \\
\hline & & $286.4(8)$ & $\mathrm{C}-\mathrm{O}$ \\
\hline & & $287.5(28)$ & $\mathrm{C}-\mathrm{O}-\mathrm{C}, \mathrm{N}-\mathrm{C}=\mathrm{O}$ \\
\hline \multirow[t]{3}{*}{$\mathrm{N}_{2}$ plasma } & ChtP4 & $285.1(60)$ & $\mathrm{C}-\mathrm{C}, \mathrm{C}-\mathrm{H}$ \\
\hline & & $286.6(19)$ & $\mathrm{C}-\mathrm{O}$ \\
\hline & & $288.0(21)$ & $\mathrm{C}-\mathrm{O}-\mathrm{C}, \mathrm{N}-\mathrm{C}=\mathrm{O}$ \\
\hline \multirow[t]{3}{*}{ Ar plasma } & ChtP5 & $284.9(49)$ & $\mathrm{C}-\mathrm{C}, \mathrm{C}-\mathrm{H}$ \\
\hline & & $286.5(37)$ & $\mathrm{C}-\mathrm{O}$ \\
\hline & & $288.4(14)$ & $\mathrm{C}-\mathrm{O}-\mathrm{C}, \mathrm{N}-\mathrm{C}=\mathrm{O}$ \\
\hline \multirow[t]{3}{*}{ Ar plasma } & ChtP6 & $284.9(52)$ & $\mathrm{C}-\mathrm{C}, \mathrm{C}-\mathrm{H}$ \\
\hline & & $286.5(30)$ & $\mathrm{C}-\mathrm{O}$ \\
\hline & & $288.1(18)$ & $\mathrm{C}-\mathrm{O}-\mathrm{C}, \mathrm{N}-\mathrm{C}=\mathrm{O}$ \\
\hline \multirow[t]{3}{*}{ Ar plasma } & ChtP7 & $285.0(55)$ & $\mathrm{C}-\mathrm{C}, \mathrm{C}-\mathrm{H}$ \\
\hline & & $286.6(28)$ & $\mathrm{C}-\mathrm{O}$ \\
\hline & & $288.2(17)$ & $\mathrm{C}-\mathrm{O}-\mathrm{C}, \mathrm{N}-\mathrm{C}=\mathrm{O}$ \\
\hline \multirow[t]{3}{*}{ Ar plasma } & ChtP8 & $285.0(73)$ & $\mathrm{C}-\mathrm{C}, \mathrm{C}-\mathrm{H}$ \\
\hline & & $286.8(14)$ & $\mathrm{C}-\mathrm{O}$ \\
\hline & & $288.3(14)$ & $\mathrm{C}-\mathrm{O}-\mathrm{C}, \mathrm{N}-\mathrm{C}=\mathrm{O}$ \\
\hline
\end{tabular}

which also overlaps $\mathrm{C}-\mathrm{NH}_{2}$ chemical bindings. The peak at $286.6 \mathrm{eV}$ was assigned to $\mathrm{C}-\mathrm{O} / \mathrm{C}-\mathrm{OH}$ and the peak at 288.3 $\mathrm{eV}$ to $\mathrm{O}-\mathrm{C}-\mathrm{O}$ and $\mathrm{N}-\mathrm{C}=\mathrm{O}$ chemical bindings. ${ }^{[34,35]}$ The same components were present in the $C_{1 s}$ core level spectra of the treated membranes, but changes in the relative intensities of all peaks were observed (Figure 3, Table 3). Generally an increase in the relative intensity of the $\mathrm{C}-\mathrm{H}$ component was observed after treatment. This change was accompanied by a decrease in $\mathrm{C}-\mathrm{O}$ intensity in almost all the treated membranes compared to the untreated one. These results confirm the acetate cleavage and the ongoing etching processes. Significant quantities of oxygen moieties (mainly $C=0$ ) were introduced on the surface for ChtP5 and ChtP8 (Table 2).

Modifications in the surface chemistry and morphology can change the surface hydrophilicity, ${ }^{[24]}$ which is one of the key surface parameters determining the material/
Table 4. Water contact angles $(\theta)$ and surface energy $(\gamma)$ of untreated and plasma-treated chitosan membranes.

\begin{tabular}{lcccc}
\hline \multirow{2}{*}{ Treatment } & Sample & $\boldsymbol{\theta}$ water & & $\boldsymbol{\gamma}$ \\
\cline { 3 - 3 } & & degrees & & $\mathbf{m N} \cdot \mathbf{m}^{-\mathbf{1}}$ \\
\hline none & CHT & $88.5 \pm 1.6$ & & $30.8 \pm 0.1$ \\
$\mathrm{~N}_{2}$ plasma & ChtP1 & $87.7 \pm 1.7$ & & $20.7 \pm 0.1$ \\
$\mathrm{~N}_{2}$ plasma & ChtP2 & $85.1 \pm 9.4$ & & $21.6 \pm 0.1$ \\
$\mathrm{~N}_{2}$ plasma & ChtP3 & $83.5 \pm 5.6$ & & $28.8 \pm 0.2$ \\
$\mathrm{~N}_{2}$ plasma & ChtP4 & $84.7 \pm 7.1$ & & $38.6 \pm 0.1$ \\
Ar plasma & ChtP5 & $78.3 \pm 9.4$ & & $21.9 \pm 0.1$ \\
Ar plasma & ChtP6 & $88.1 \pm 3.3$ & $31.8 \pm 0.1$ \\
Ar plasma & ChtP7 & $84.9 \pm 4.4$ & $32.4 \pm 0.3$ \\
Ar plasma & ChtP8 & $93.7 \pm 2.6$ & & $18.0 \pm 0.2$
\end{tabular}


bioenvironmental interactions. The measured contact angles and calculated surface energies of the prepared membranes are summarized in Table 4 . Generally, all the treatments resulted in more hydrophilic surfaces. Previous works ${ }^{[29,36]}$ have demonstrated that short time (1-3 min) treatments in a nitrogen atmosphere result in more hydrophilic surfaces. In contrast, longer treatments (i.e., $>3 \mathrm{~min}$ ) decrease the surface hydrophilicity. The obtained results for the surface energy are in agreement with the ones from XPS analysis. Different trends were observed for the used working atmospheres. A slight increase of the surface energy with the treatment time was observed for the samples treated by nitrogen plasma. An intermediate exposure time was found to result in highest surface energy, when argon was used as a working gas. Earlier studies ${ }^{[37,38]}$ reported that materials with a high surface energy promote rapid cellular adhesion and spreading, whereas low surface energy does not favor such behavior. It has been also shown by different studies ${ }^{[2,39]}$ that changes in the surface charge, chemical surface composition and roughness can affect the biocompatibility of a polymer.

The results obtained from the MTS assay (Figure 4) showed that both nitrogen and argon plasma treated membranes promoted a higher cell viability than untreated chitosan membranes. This effect was observed for all the studied time periods. After $14 \mathrm{~d}$ of culture, the ChtP2 sample presented the highest cell viability among the nitrogen plasma treated membranes. The values obtained for the membranes treated with argon plasma were more consistent, regardless of the culture time.
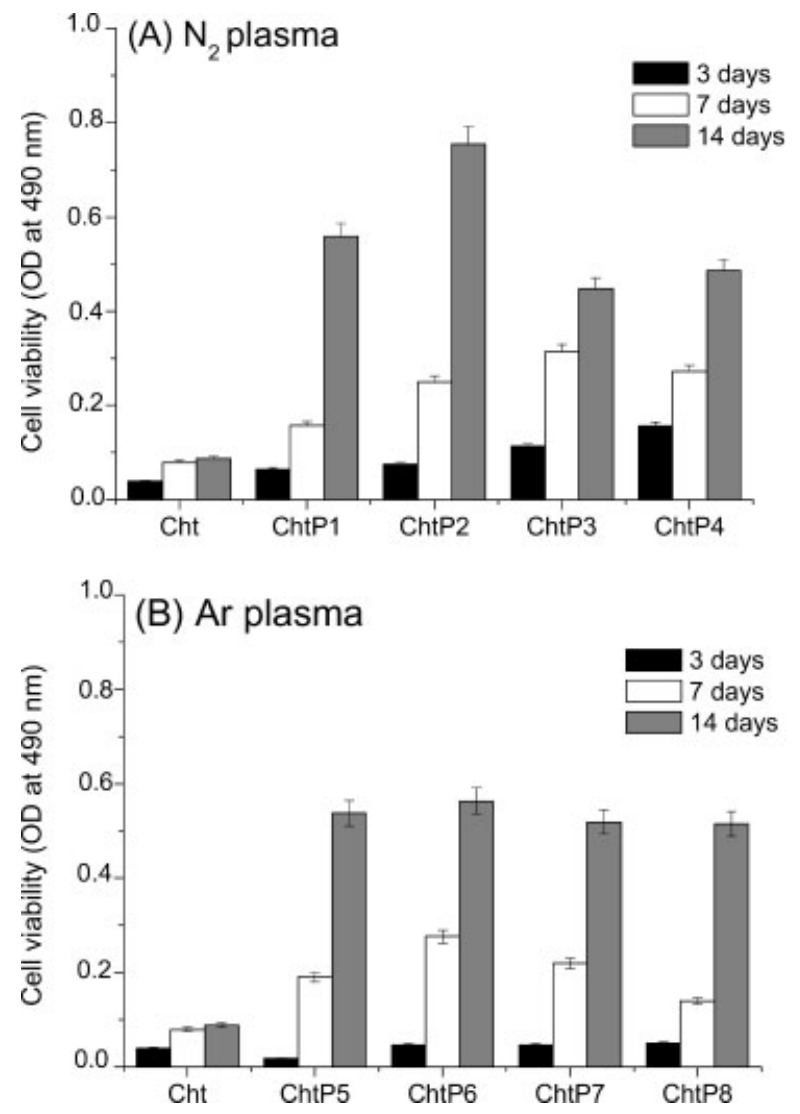

Figure 4. Viability levels of L929 fibroblasts-like cells on the untreated and treated plasma membranes assessed by MTS assay. (A) ChtP1, ChtP2, ChtP3, ChtP 4 - samples after nitrogen plasma, and (B) ChtP5, ChtP6, ChtP7 and ChtP8 - samples after argon plasma.

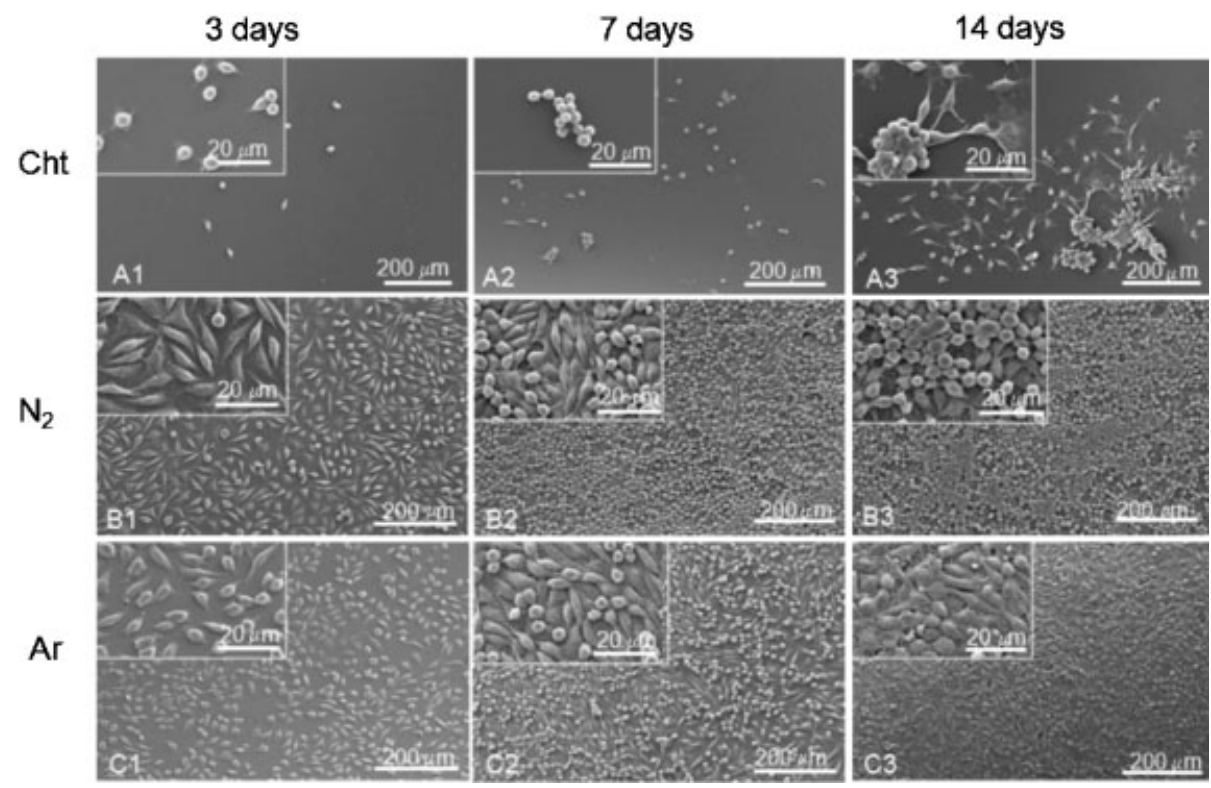

Figure 5. SEM micrographs of L929 fibroblast-like cells cultured on: (A) Cht (untreated membrane - control); (B) ChtP2 (chitosan membranes modified by nitrogen plasma); (C) ChtP6 (chitosan membranes modified by argon plasma), after 3, 7 and $14 \mathrm{~d}$ of culture. 
Cell morphology on both untreated and modified membranes was observed by SEM. Fibroblast-like cells were able to attach and stretch on all the types of modified membranes after different culture times. The ChtP2 sample, which presented the best results among nitrogen treated membranes, was selected to be studied for different culture periods. The ChtP6 from the argon modified membranes was also chosen in order to evaluate the effect of the working gas on cell morphology. After $3 \mathrm{~d}$ of culture, there was a significant number of L929 cells on the surface of both nitrogen and argon treated plasma membranes (Figure 5).

The attached cells presented a typical morphology for fibroblasts with an elongated shape. The number of attached cells increased with culture time and, after $14 \mathrm{~d}$, a dense cellular monolayer covered both modified membranes. On the contrary, and as previously described, ${ }^{[16,17]}$ poor cell attachment was observed for the untreated membranes. After $3 \mathrm{~d}$ of culture, only a few rounded cells could be seen on their surface. This number increases with the time of culture, but at the end of the studied period it was still insignificant compared to the number of cells adhered to the modified membranes.

\section{Conclusion}

Surface modification of chitosan membranes was performed using nitrogen and argon plasma. Higher surface roughness (nanoscale) measured for the modified materials indicated etching processes. This effect increased with the exposure time and did not depend on the working atmosphere used. The surface energy increased for the treated membranes compared to the untreated ones. XPS measurements confirmed the incorporation of oxygenand nitrogen- containing groups on the surface after treatments. In vitro preliminary biological studies showed that modified chitosan membranes displayed higher cell viability on the surface when compared to untreated chitosan membranes. The results demonstrated that either nitrogen or argon plasma treatments can be used as a way to improve the fibroblast adhesion and proliferation of chitosan membranes. The proposed modifications would facilitate the use of chitosan and chitosan based materials in wound dressing and tissue engineering applications.

Acknowledgements: The authors acknowledge funding from the Portuguese Foundation for Science and Technology (FCT), Portugal, for providing grants SFRH/BD/8658/2002, SFRH/BPD/17584/2004 and SFRH/BPD/8191/2002, Programme Alßan, the European Union Programme of High Level Scholarships for Latin America (E04M041362CO), and the EU funded Project HIPPOCRATES
(NMP3-CT-2003-505758). This work was carried out under the scope of the European NOE EXPERTISSUES (NMP3-CT-2004-500283).

Received: October 17, 2007; Revised: December 24, 2007; Accepted: January 4, 2008; DOI: 10.1002/mabi.200700264

Keywords: biopolymers; cellular response; chitosan; plasma surface modification; wound dressings

[1] R. Lanza, R. Langer, J. Vacanti, "Principles of Tissue Engineering", Academic Press, London 2000, p. 857.

[2] M. Bradley, N. Cullum, E. A. Nelson, M. Petticrew, T. Sheldon, D. Torgerson, Health Technol. Asses. 1999, 3, 1.

[3] Y. Qin, J. Appl. Polym. Sci. 2004, 91, 953.

[4] L. L. Lloyd, J. F. Kennedy, P. Methacanon, M. Paterson, J. Knill, Carbohydr. Polym. 1998, 37, 315.

[5] W. Paul, C. P. Sharma, Trends Biomat. Artif. Organs 2004, 18 , 18.

[6] R. M. Silva, J. F. Mano, R. L. Reis, J. Mater. Sci: Mater. Med. 2004, 15, 105.

[7] A. K. Azad, N. Sermsintham, S. Chandrkrachang, W. F. Stevens, J. Biomed. Mater. Res. B 2004, 69B, 216.

[8] K. R. Kirker, Y. Luo, J. H. Nielson, J. Shelby, G. D. Prestwich, Biomaterials 2002, 23, 3661.

[9] M. G. Jeschke, G. Sandmann, T. Schubert, D. Klein, Wound Repair Reg. 2005, 13, 324.

[10] W. H. Chang, Y. Chang, P. H. Lai, H. W. Sung, J. Biomat. Sci. Polym. E 2003, 14, 481.

[11] C. Valenta, B. G. Auner, Eur. J. Pharm. Biopharm. 2004, 58 279.

[12] M. N. V. R. Kumar, Chem. Rev. 2004, 104, 6017.

[13] M. G. N. Campos, C. R. F. Grosso, G. Cardenas, L. H. I. Mei, Macromol. Symp. 2005, 229, 253.

[14] H. Zheng, Y. Du, J. Yu, R. Huang, L. Zhang, J. Appl. Polym. Sci. 2001, 80, 2558.

[15] C. Peniche, W. A. Monal, H. Peniche, N. Acosta, Macromol Biosci. 2003, 3, 512.

[16] S. S. Silva, M. I. Santos, O. P. Coutinho, J. F. Mano, R. L. Reis, J. Mater. Sci.: Mater. Med. 2005, 16, 575.

[17] C. Chatelet, O. Damour, A. Domard, Biomaterials 2001, 22 261.

[18] F. Yang, X. Li, M. Cheng, Y. Gong, N. Zhao, X. Zhang, J. Biomater. Appl. 2002, 16, 215.

[19] V. Tangpasuthadol, N. Pongchaisirikul, V. P. Hoven, Carbohydr. Res. 2003, 338, 937.

[20] H. T. Wang, Y. E. Fang, Y. S. Yan, J. Mater. Chem. 2001, 11, 1374

[21] Y. P. Li, L. Liu, Y. E. Fang, Polym. Int. 2003, 52, 285.

[22] X. Zhu, K. S. Chian, M. B. E. Chan-park, S. T. Lee, J. Biomed. Mater. Res. A 2005, 73A, 264.

[23] P. M. L. Pérez, A. P. Marques, R. M. P. Silva, I. Pashkuleva, R. L. Reis, J. Mater. Chem. 2007, 17, 4064.

[24] P. K. Chu, J. Y. Chen, L. P. Wang, N. Huang, Mat. Sci. Eng. R 2002, 36, 143.

[25] F. A. Khonsari, M. Tatoulian, N. Shahidzadeh, J. Amouroux, "Study of the plasma treated polymers and the stability of the surface properties", Springer-Verlag, New York 1998, p. 165.

[26] C. M. Alves, Y. Yang, D. L. Carnes, J. L. Ong, V. L. Sylvia, D. D. Dean, C. M. Agrawal, R. L. Reis, Biomaterials 2007, 28, 307.

[27] A. A. M. Plath, K. Schroder, B. Finke, A. Ohl, Vacuum 2003, 71, 391.

[28] L. J. Gerenser, J. M. Grace, G. Apai, P. M. Thompson, Surf. Interface Anal. 2002, 29, 12. 
[29] N. V. Bhat, D. J. Upadhyay, J. Appl. Polym. Sci. 2002, 86, 925.

[30] A. Hirai, H. Odani, A. Nakajima, Polym. Bull. 1991, 26, 87.

[31] D. K. Owens, R. C. Wendt, J. Appl. Polym. Sci. 1969, 13, 1741.

[32] R. L. Reis, S. C. Mendes, A. M. Cunha, M. J. Bevis, Polym. Int. 1997, 43, 347.

[33] A. J. Salgado, M. E. Gomes, A. Chou, O. P. Coutinho, R. L. Reis, D. W. Hutmacher, Mater. Sci. Eng. C 2002, $20,27$.

[34] G. Beamson, D. Briggs, "High Resolution XPS of Organic Polymers", John Wiley \& Sons, Chichester 1992.
[35] L. J. Matienzo, S. K. Winnacker, Macromol. Mater. Eng. 2002, 287, 871.

[36] C. M. Chan, T. M. Ko, H. Hiraoka, Surf. Sci. Rep. 1996, $24,1$.

[37] S. A. Mitchell, M. R. Davidson, R. H. Bradley, J. Colloid Interface Sci. 2005, 281, 122.

[38] K. Anselme, Biomaterials 2001, 21, 667.

[39] B. D. Ratner, A. S. Hoffman, F. J. Schoen, J. E. Lemos, "Biomaterials Science: An Introduction to Materials in Medicine", Academic Press, New York 1996, p. 141. 